（粘土）に對して明に區別するてとが出來ると共に砂の化學成分の大體を推察し得て分析の結果を豫 測する事が出來且其他の重要なる諸性質をる知る事が出來る（砂粒の形狀の結果に對する考察參照）。

（-4）IV. 几述べた如き方法は任意の砂を選擇し丈は或砂の適否を識別するに有力な方法であると 考へる。

（5）鋀鋼用の我國の砂と外國の砂とを上記實驗に於て得たる結果にて比較すると我國の砂は

(i) 粘土分が少ない故に使用に當りて粘土を加人るの手数を要する(第一圖其二参照)。

(ii) $\theta$ 小である即粒位の不揃を示してをり又細汁類を比較的多く含むから通氣性は惡くなり膯で ある(第三圖其三、其四寥照)。

(iii) 砂粒の形狀に於て人工による砂 ホ が大部分を占め僅に自然砂 イを含むに反し外國砂は. 全部天然のものであつて殊にイに屬するものが多い。この事は粉碎の手數を省き且型の各部の均等 なものを造るに與つてカある。(第四圖及第 6 表寥照)。

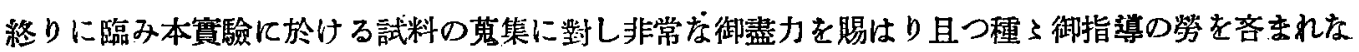
かつた金子恭輔博士に心から御禮申上げ同時に賽驗に關しては終始下村益太郎君の御助力を仰いだ事 を附記して厚く感謝する次第である。

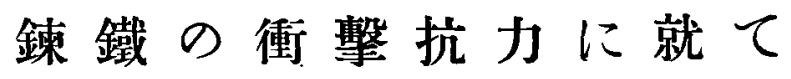

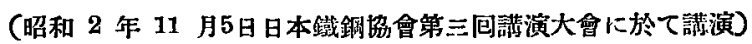

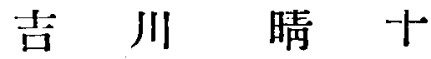

\title{
Impact Tests of Strained Wrought Iron and Cast Steel.
}

By H. Kiknawa, Member.

In the proof tests of chain cables and crane chains in several leading countries, it is required that the chain should stand a load which is nearly $72 \%$ of the breaking strength.

Wrought iron may, however, become brittle after it was strained by a stress beyond a certain limit and if this embrittling occur by the proof test, the chain will be used in a brittle condition after the test, which must, therefore, be revised.

Izod tests were made on test-pieces taken from three samples of wrought iron, which were strained to various degrees by a tensile testing machine to know the limit and the extent of embrittling by the strain.

The same tests were made on test pieces of a low carbon cast steel, as cast steel is: often employed for chain cables recently.

The results of tests were as follows: -

(1) The Izod value of wrought iron is reduced after it was strained by a tensile stress over $60 \%$ of the breaking strength.

(2) The degree of embrittling is variable according to the material, some samples become only slightly brittle and the others lose.nearly 2/3 of their impact value after they were loaded about $72 \%$ of the breaking stress. 
(3) In some cases the impact value of strained samples is greatly reduced at low temperatures while non-strained material remains the same.

(4) Low carbon cast steel becomes brittle by strain when stressed in the annealed state, but it does not when it was hardened and tempered.

It may thus be concluded that either the proof test for chains specifying excess load should be reasonably altered or thc chains must be properly heat-treated so that the impact value will not be reduced by the strain of the proof test

FINIS —

\section{I 緒宮}

低炭素鋼が或る程度の應力を受けるる組織に變化を起し、再結晶させて見ると結晶が大をくなると 云ふ事は前から知られて居つた。又斯くの如き場合には其材料が脆くなると云ふ事も知られて居た。 文献に低んば炭素 0.04\%から 0.12\% 位迄に此現象が起り炭素の非常に少ないるのゃ $0.12 \%$ より

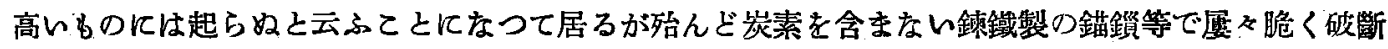

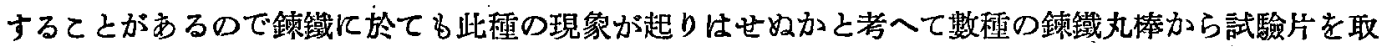
ウ之れを一旦率引試驗機てかけて大小種にの街重をが然る後其物から衝擊試驗片を作つてアイジツ ト式衝撃試驗を行ひそれに作つて破斷力の何％の應力を加へをるのは元來の衝撃抗力の何％に衝摹 抗力を減するかを測定して見をらば或ものは大して衝撃抗力を減少しないが或ものは倏重 $61 \%$ で既 几著しく抗力を減し $72 \%$ では衝擊値約 1/3 になる。そして一般に倚重の大きい程衝擊抗力の減じ方

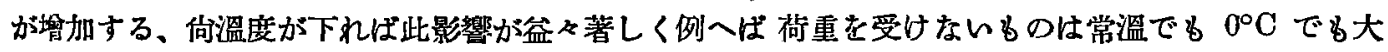
差はないが $80 \%$ 荷重を受けたものは $0^{\circ} \mathrm{C}$ て於て衝撃值が荷重を受けないものに比し牛減する如き ものもある。

錨䥊或は起重機用䥊等は製造後緊張試驗（Proof test)を行ふてとになつて居て其規格は日本でも英 國でも其鑽の緊張破斷力の約 72\% の力で引張つて見る事になつて居るが材料が斯かる大きな應力を 加へられたが雹めに衝撃抗力を失ふとすれば出來上つた鎻に緊張試驗を施すと云ふ事岋折角の製品を 惡くして實用に供すると云ふ事になり斯かる試驗規格は改める必要があると云はねばならぬ、尤も斯 くの如く街重を受けたが䉆めに衝慗抗力を減する事賽の原因がわかり其除去方法も檴ぜられたならば 充分の緊張試驗を行つた方が勿論安全であるから此現象の原因を完める事も必要である。

\section{II 供 試 材 料}

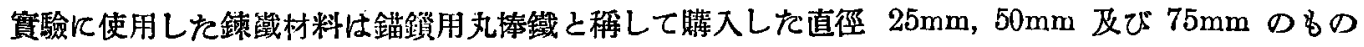

2 種で其分析成分第 1 表に揭ぐる通り何れる略ふ相似たるのである。

\section{第 1 表試路材分析成分}

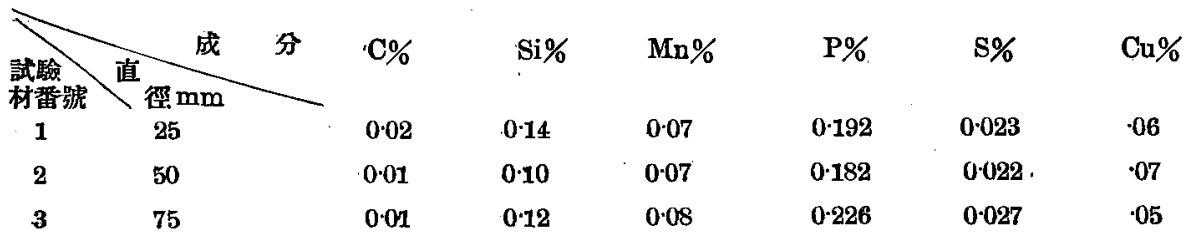


試驗材の端面に於ける硫黃印畫は第 1 圖に示す通り試材番號 1 及び 2 は積重ねて鍛接したものであ るが試材番號 3 は䅡重权た周圍を更に包みて鐉接したものである。

\section{III 試 驗 分 法}

試驗の要領は試驗材丸棒の端から先づ牽引試驗片及び衝擊試驗片を探つて其睢の常態に於ける抗張 カ及び衝擊抗力を試驗し次に平行部の長さ $150 \mathrm{~mm}$ 直徑 $19 \mathrm{~mm} の$ 試驗片を探り辛引試驗機で常態に 於ける最大抗張力の $61 \%$ 乃至 $90 \%$ の荷重をかけ然る後其試驗片から衝擊試驗片を作りアイッット

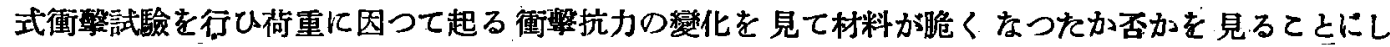
た。

鍊臷は穖維の方向によつて衝撃試驗の成績も著く異なるから出來る丈け一樣の成績を得る雹めに衝 撃試驗片は第 1 圖記大の如く何えも切迈を斷面緎維の流れに平行に作る如く探取した、試驗片探取の 位通及び切込の付け方を第 2 圖に示す。

直徑 $25 \mathrm{~mm}$ のものは中央から丈け試驗片を探つたから長さが大變長くをつた從つて兩唏の差異を

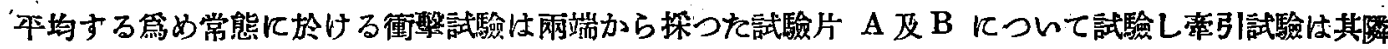

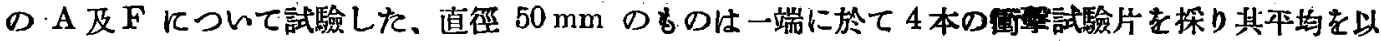
て常態に於ける衝摮值とし其隣の A 及他端の $\mathrm{F}$ で旁引試驗を行つた。直徑 75mm のものは同樣8 本の衝擊試驗片の平均を取り星引試驗は其隣の A 及 $\mathrm{D}$ の值を以て常態の值とした、尚直徑 $75 \mathrm{~mm}$ のものは叓引試驗片も一断面にて 2 本宛並べて採つたから全長が短くて兩端の差も少ない譯である。

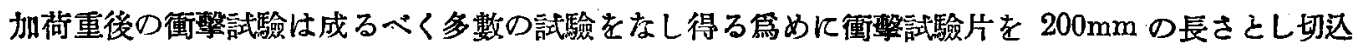
を 5 ケ所作り 5 间試驗を行つた、加荷重試驗に於て永久變形量は $150 \mathrm{~mm}$ に付最大 $9 \%$ 內外だから試 驗片の標點間に於ける應力注先づ均一をものと見て 5 ケ所の試驗成績の平均を以て其常態に於ける成 績と比較すべき值とした。

\section{IV 試 驗 結 果}

（a）常溫の場合：一一先づ常態に於ける䇣引及び衝擊試驗成續を見て其破斷力に對する何\%かか荷 重をかけ其物から衝蒰試驗片を作つて試驗を行ひ常態の衝媻抗力と加荷重後の衝繋抗力とを比较する のであるが常態に於ける成績は第 2 表の通りで此試驗材料は延伸率は少ないが㣫般試驗は先づ普通の ものと云へる。

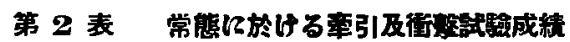

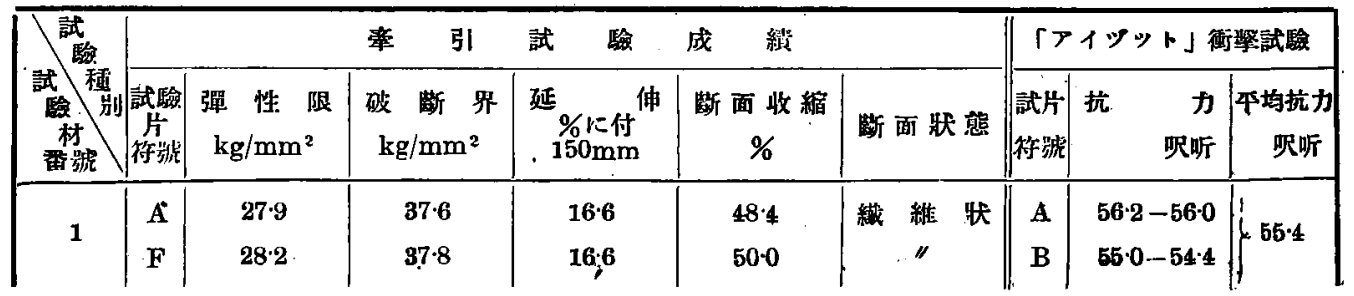




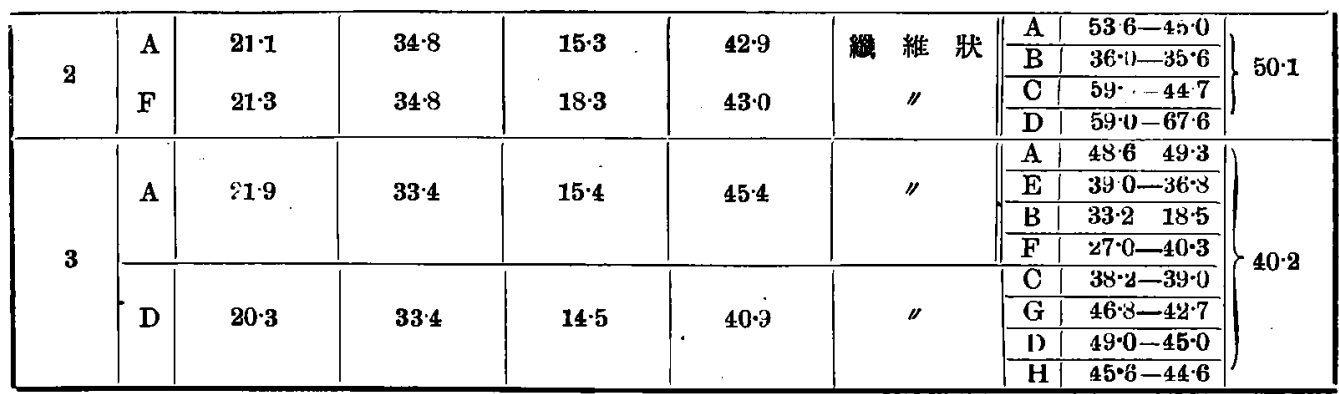

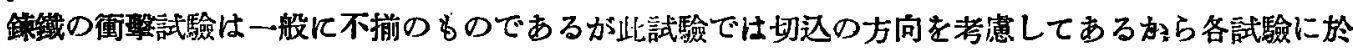
て大した差は無ん、從つて此位の數つ試羷をして見れば大抵其變化の狀況がかかる臎である。

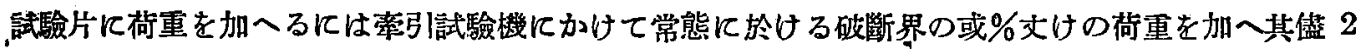
分間置き荷重を去る、そして永久變形を見る雼めに鳔點間の長さの延伸と直徑收縮とを見た、各試驗 片に加へた荷重と夫れによる永久變形量は第 3 表の通りである。

第 3 表 加荷重量並に永火辈形量

\begin{tabular}{|c|c|c|c|c|c|c|c|c|}
\hline 試驗材 & 試驗片 & 加荷重 $\times 100$ & 加 & 荷重 & 永 & 整 & 形 & \\
\hline 番 號 & 称 號 & 破斷界 $\times 100$ & & $\mathbf{k g} / \mathbf{m m}^{2}$ & $\begin{array}{l}\text { 延 伸 } 150 \mathrm{~mm} \\
\text { に付\% }\end{array}$ & 收 & 緶 \% & 記 \\
\hline \multirow{4}{*}{1} & $\mathbf{B}$ & 72. & & $27 \cdot 2$ & 28 & & $2 \cdot 5$ & \multirow{12}{*}{ 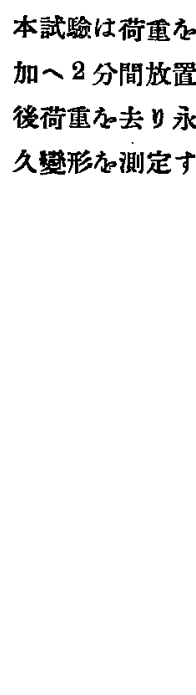 } \\
\hline & C & $78^{\circ}$ & & 295 & $4: 1$ & & $3 \cdot 7$ & \\
\hline & $\mathbf{D}$ & $84^{\circ}$ & - & $31 \cdot 8$ & $5 \cdot 7$ & & $5 \cdot 0$ & \\
\hline & $\mathbf{E}$ & $90^{\circ}$ & & $34 \cdot 0$ & $9 \cdot 5$ & & $8 \cdot 3$ & \\
\hline \multirow{4}{*}{$\mathbf{2}$} & B & 61. & & $21 \cdot 2$ & $2 \cdot 0$ & & $2 \cdot 1$ & \\
\hline & $\mathbf{C}$ & 72 & & $25 \cdot 1$ & $\mathbf{3} \cdot \mathbf{1}$ & & 29 & \\
\hline & D & 80 & & $27 \bullet 8$ & $5 \cdot 1$ & & $4 \cdot 7$ & \\
\hline & $\mathbf{E}$ & 90 . & & $31: 3$ & $8 \cdot 8$ & & $7 \cdot 5$ & \\
\hline \multirow{4}{*}{3} & B & 63. & . & $21 \cdot 0$ & 1.9 & & $1 \cdot 6$ & \\
\hline & $\mathrm{C}$ & 72 . & & $24 \cdot 0$ & $3 \cdot 1$ & & $3 \cdot 0$ & \\
\hline & $\mathbf{E}$ & $80^{\circ}$ & & $26 \cdot 7$ & $4 \cdot 4$ & & $4 \cdot 5$ & \\
\hline & $\mathbf{F}$ & 90 & & $30 \cdot 0$ & $7 \cdot 8$ & & $6 \cdot 9$ & \\
\hline
\end{tabular}

試驗材番號 1 から探つた試驗片に對しては破斷界の $72 \%$ に相當する荷重から始めで $90 \%$ 迄の荷 重をかけた。之れはロイドの錨䥊試驗規格が錨鏆の䂝斷力の約 $72 \%$ で引張つて見ると云ふてとにな つて居るから此位の荷重を加へたものが影響を受けはせぬかどらかと云ふ事を知らんが䉆めでする。 試材番號 2 及び 3 ののに對しては其彈性限が常態に於ける破斷界の夫れネネ $61 \%$ 及で $63 \%$ に 相當するから其荷重即ち彈性限迄の應力を受けたものが影響を受けるや否やを見る䉆めに其荷重をか 
けて試驗した、之れ等の荷重に因つて起つた永久變形量は長さ直徑共彈性限附近に拎て䄪 $2 \%$ 、破斷 界の $90 \%$ 附近几於て約 $8 \%$ 內外である。

荷重を加へた媵其物から衝酻試驗片を作つてアイッット式試驗を行つた結果は第 4 表の通り衝撃抗 カに大をる變化を起してるる。

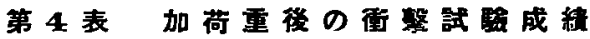

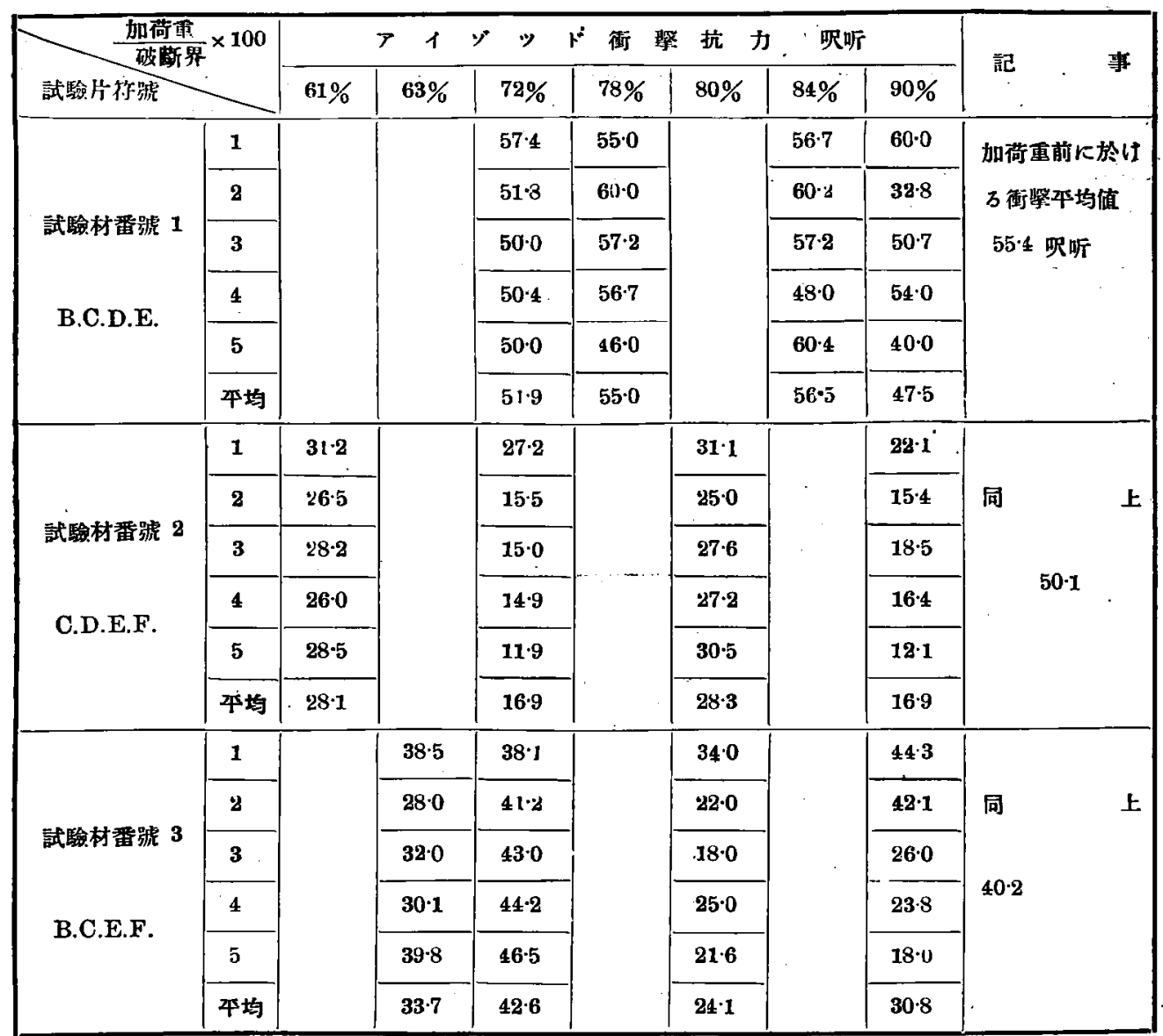

簡明の鶷めに第 4 表中平均值丈けを再揭して見ると第 5 表の通りになる。

第万表加荷重前嵝の平均街祭值

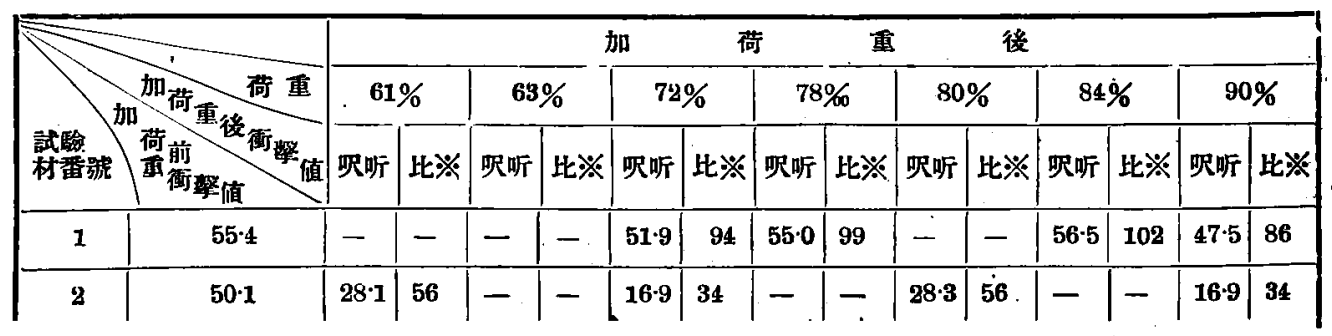




\begin{tabular}{|c|c|c|c|c|c|c|c|c|c|c|c|c|c|c|}
\hline 3 & $40 \cdot 2$ & - & - & 33.7 & 84 & $42 \cdot 6$ & 106 & - & $24 \cdot 1$ & 60 & - & - & 30.8 & 77 \\
\hline
\end{tabular}

上表で衝盤抗力の變化を見るに試驗材によつて抗力減少の程度に差がある。試驗材 2 は最も著しく 減少し破斷界の $61 \%$ に相當する倚重を加へた時既に衝撃抗力は約牛分に減少する.72\%及び $80 \%$ では何れの試驗材当減少し $84 \%$ K於て試嬐材番號 1 が却つて幾分增加するのを見るが $90 \%$ に至 つては何れる大に減少する。

試驗材番號 2 のむのが變化が特に著しいから更に試驗片を作つて破斷界つ $50 \%$ 以上の荷重をかけ て追加試驗をして見た、試驗片の探取方法は前と同樣で常態の睢及び荷重を50\%及び $61 \%$ \%けて 後衝擊試驗をして見た結果は第 6 表の通りで常態の監の試驗片 E. F. G. H.の本均は 45.5 吹听で 最初試驗の時の 50.1 呎听と大差がない。50\%加荷重後の G 1. 2. 3. 4. 5. の本均は 40.9 呎听で加荷 重前に比し大して減少して居らぬ。61\%加荷重後のH1. 2. 3. 4. 5. の平均は 34.3 吹听で最初の試 驗(第 4 表) 28.1 呎听に比しよほど大さいが加荷重前に比しては著しく減少して居る、即ち此材料は

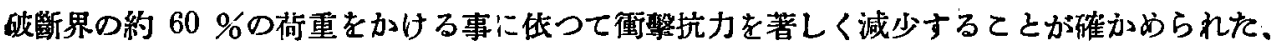

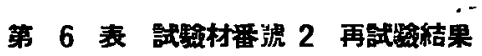

\begin{tabular}{|c|c|c|c|c|c|}
\hline \multicolumn{2}{|c|}{ 其 儒 } & \multicolumn{2}{|c|}{$50 \%$ 加荷重挠 } & \multicolumn{2}{|c|}{$61 \%$ 加诃重後 } \\
\hline 試片梅號 & 街 淔 & 試片篗躆 & 衙繁值 & 試片符號 & 衙 㢣 值 \\
\hline $\mathbf{E}$ & $47 \cdot 0-41 \cdot 1$ & G 1 & $42 \cdot 0$ & H 1 & $' 46.7$ \\
\hline F & $38 \cdot 5-35 \cdot 2$ & $\mathrm{G} 2$ & $42 \cdot 0$ & H2 & $35 \cdot 2$ \\
\hline G & $48 \cdot 0-49 \cdot 1$ & G 3 & $49 \cdot 8$ & $\mathbf{H} \mathbf{3}$ & $28 \cdot 0$ \\
\hline H & $52 \cdot 0-52 \cdot 8$ & G 4 & $40-7$ & H 4 & 35.7 \\
\hline- & $-\cdot$ & G5 & 29.8 & H 5 & $26 \cdot 0$ \\
\hline 平 均 & 45.5 & 平 均 & 40.9 & 平 均 & $34 \cdot 3$ \\
\hline
\end{tabular}

（b）低溫の場合:一一低溫度に於ては鉬鐵。低炭素鋼等が著しく衝撃抗力を減ず事は周知の事實 であるが斯かる場合に像め荷重を加へられたものが如何なる程度に衝撃抗力を減少するかと云ふ事を

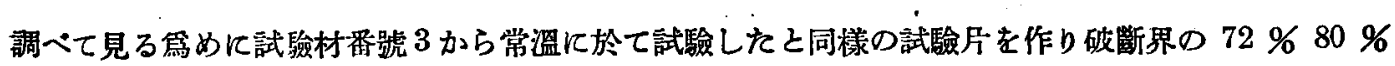
及び $90 \%$ 背重をかけ $0^{\circ} \mathrm{C}$ に冷却して衝整試驗を行ひ一方に荷重を加へないるのの $0^{\circ} \mathrm{C}$ に於ける 衝擊抗力を測定して其溫度での抗力減少程度を比較した。

其結果を第 7 表に揭げる。 


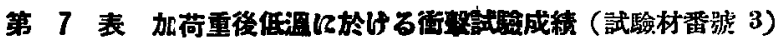

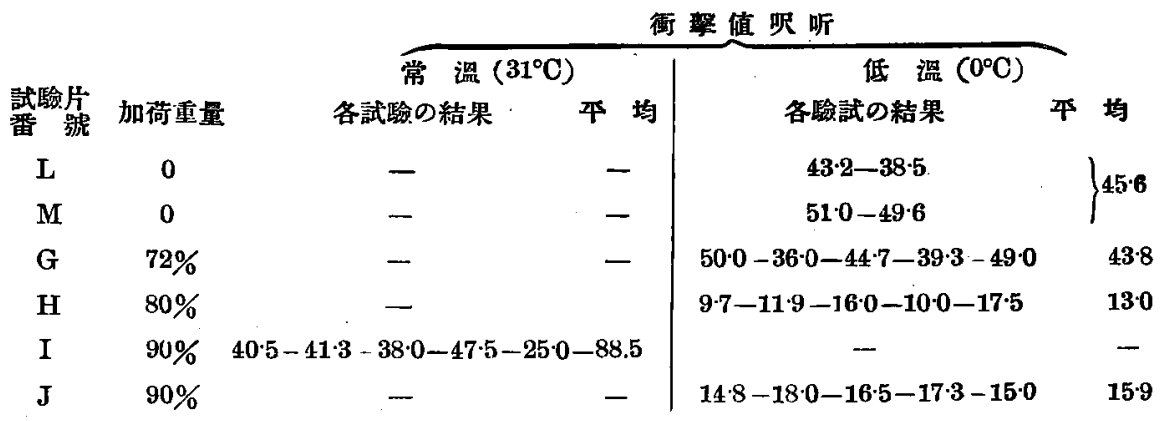

上表中嗬重を加へない I 及び $\mathrm{M}$ の平均衝撃值が $45^{\circ} 6$ となつて居るが之れを第 2 表の平均 40.2 に比較すると却て 5.4 吹听即ち 13 \%餘增加した事になる、别に錨顉の試驗材でやつて見た所による と 9.5\%衝盤抗力を減少したものもあつた、然るに加荷重後のものは上钎成績を第 4 表の常溫のも のに比へて見れば $0^{\circ} \mathrm{C}$ に於ては皆衝撃抗力を減して居る。それを一つの表に緌めて見ると第 8 表の 通りで $90 \%$ 加荷重後のるの恃 $0^{\circ} \mathrm{C}$ に於て常溫の約 $1 / 2$ にをる、

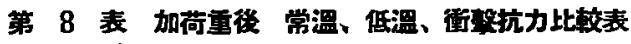

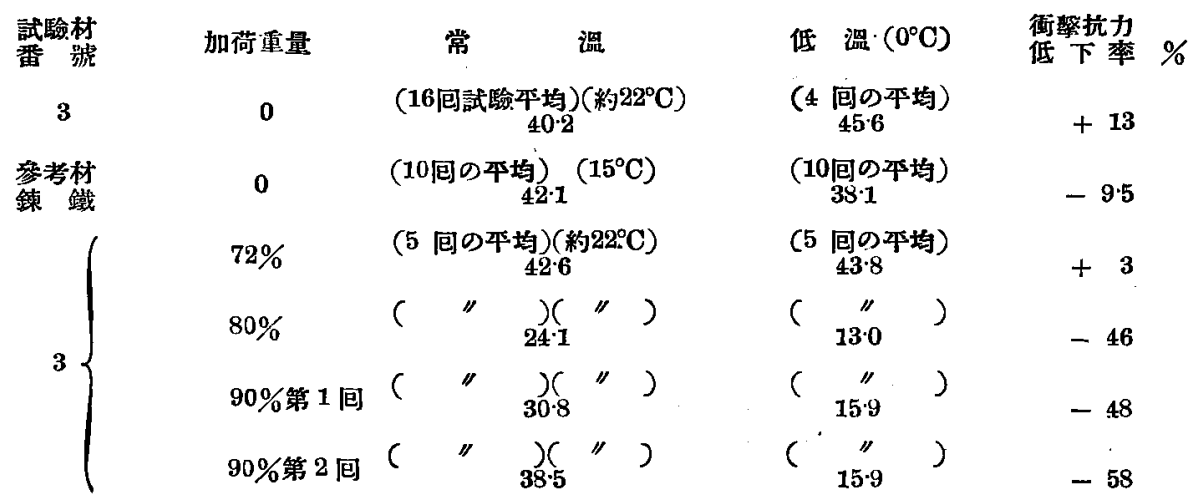

即ち荷重を加へたるのは其第めに常溫に於ても既に衝擊抗力を滅する上に向寒喻に對する感受性が 大となる雼めに更に衝擊抗力を減する事となる。

(c) 試驗結果沉對する考察

以上の結果を略言すれば次の通りとなる。

試驗材番號 1 は衝䡈抗力の減少著しからず。

試驗材番號 2 は加荷重 $61 \%$ \%既に著しく衝盤抗力を減じ $72 \%$ では約 $1 / 3$ となる、 試驗材番號 3 は加荷重 $72 \%$ では衝盤抗力減少しないが 80 \%では常態の $60 \%$ 位に低下する。 試驗材番號 3 の $0^{\circ} \mathrm{C} に$ に於ける衝撃抗力は荷重をかけない時は常溫の場合と㱠んど異ならないが破 斷力の $80 \%$ 以上荷重をかけたるのは常溫の時の約 $1 / 2$ になる. 即ち衝擊抗力は加荷重の爲めに減ま 


\section{る上に寒冾の影響で更に牛減する。}

そてで錨鎖或は起重機用䥊の試驗規格 (Proof test) は第 9 表の如く英國は破斷力の $72 \%$ 、米國 は約 $50 \%$ 、日本の滤信省令第76號も英國のものと略飞同樣である、

\section{第 9 表 籍の試躢荷重}

\begin{tabular}{|c|c|}
\hline 會社名或は委員會名 & $\frac{\text { Proof test, ton }}{\text { A verage breaking, ton }}$ \\
\hline \multicolumn{2}{|l|}{ Pennsylvania Rail Road } \\
\hline (Specification of Crane Chains) & $50 \cdot 0$ \\
\hline \multicolumn{2}{|l|}{ Bradiee \& Co. Philadelphia } \\
\hline (Crane Chains) & $50 \cdot 0$ \\
\hline \multicolumn{2}{|c|}{ Commitee of the U. S. Testing Board } \\
\hline (Chain Cable) & $47 \cdot 5$ \\
\hline \multicolumn{2}{|l|}{ Lloyd's Table } \\
\hline (Chain Cable) & $72 \cdot 0$ \\
\hline \multicolumn{2}{|l|}{ British.Admiralty } \\
\hline (Chain Cable) & 約 72.0 \\
\hline
\end{tabular}

然るに鍊鐵は本害驗で確かめられた如く一旦彈性限以上の荷重を受ければ㣫撃抗力を減する、其減 少程度は荷重の增大に從ひ顯著になつて破斷力の $90 \%$ \%相當する荷重を受ければアイゾツト衝整值 1/3にも減少するものがある。殊に 80 \%以上の街董を受けたものを冷却すれば寒椧の影響によつて 更に衝媻抗力を減少し $0^{\circ} \mathrm{C}$ に於て既に $1 / 2$ 位になるものさへある、而して鑽の緊張試驗に於ては其 應力のかつり方が必ずしも均一でなく部分的には破斷力の $80 \%$ 以上にも莘する所が無いとも限らな いから英國或は我國の試驗規格の如く破斷力の $72 \%$ と云ふヤうな大きな力を以て試驗するてとは出

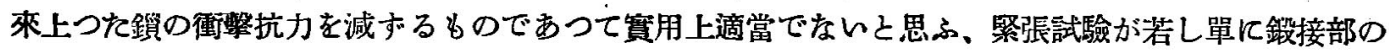
試驗等の爲め丈けだとすれば米國規格の如く破斷力の $50 \%$ 內外で試驗するが適當である。

\section{V. 鑄鋼材料試驗結果}

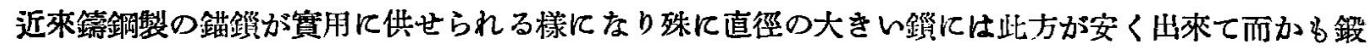

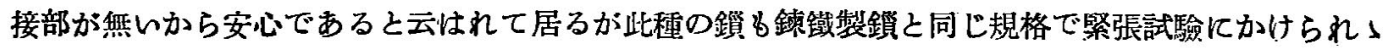
ば低炭素鋼は鍊驖よりも一層加街重によつて脆くなるものであるから售更斯かる試驗は不適當の翋で

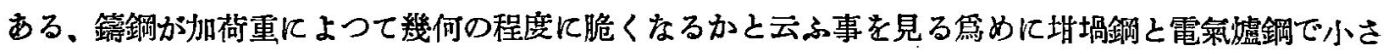

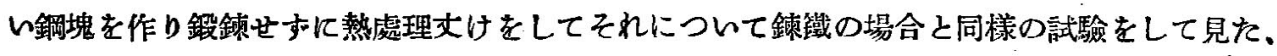

供試籌鋼の分析成分は第 10 表の通白極低炭素である、

第 10 表、銀龬試鷠材分析表

\begin{tabular}{|c|c|c|c|c|c|c|c|c|c|}
\hline 試臨材番號 & 銅程及凬塊大サ & $\mathrm{C} \%$ & $\mathrm{Si} \%$ & Mn\% & $\mathrm{P} \%$ & $\mathrm{~s} \%$ & $\mathrm{Ni} \%$ & Cr\% & $\mathrm{Cu}$ \\
\hline 4 & 诗 城 鋼 $23 \mathrm{~kg}$ & $\cdot 10$ & .06 & -22 & $\cdot 072$ & .055 & - & - & - \\
\hline 5 & 留氣烧䥄 $200 \mathrm{~kg}$ & $\cdot 10$ & 07 & -15 & .020 & 029 & 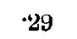 & 31 & \\
\hline
\end{tabular}




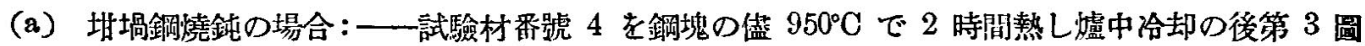

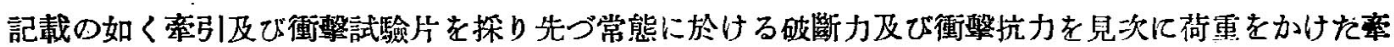

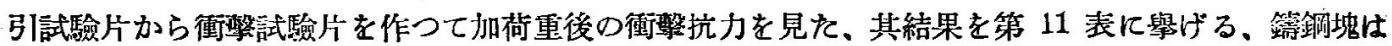
外側に生ずる柱师結晶の工合等により物理的性質を異にするから試驗片探取方法にも注意を排つて第 3 圖の如く試驗片を探取したのである。

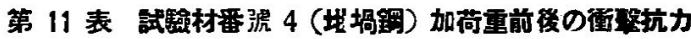

\begin{tabular}{|c|c|c|c|c|}
\hline \multicolumn{5}{|c|}{ 犁 引 試 㯺 } \\
\hline 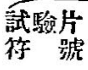 & $\begin{array}{l}\text { 彈性 限 } \\
\mathrm{kg} / \mathrm{mm}^{2}\end{array}$ & $\begin{array}{l}\text { 磂 } \\
\mathrm{kg} / \mathrm{mm}^{2} \mathrm{~mm}^{2}\end{array}$ & 延 & 收 $\%$ \\
\hline $\mathrm{C}$ & $24: 3$ & 40.3 & $37 \cdot 0$ & $59 \cdot 2$ \\
\hline
\end{tabular}

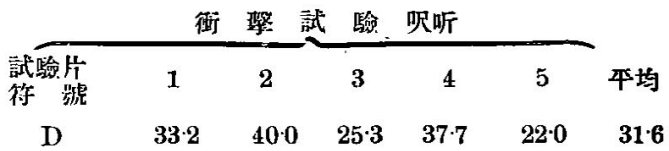

加荷車試驗.

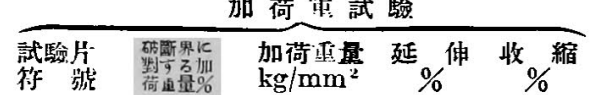

$\begin{array}{lllll}\text { A } & 60 \cdot & 24 \cdot 2 & 1 \cdot 6 & 1 \cdot 6 \\ \text { B } & 72 \cdot & 29 \cdot 0 & 3 \cdot 6 & 3 \cdot 5 \\ \text { E } & 80^{\cdot} & 31 \cdot 6 & 5 \cdot 1 & 4 \cdot 8 \\ \text { F } & 90 \cdot & 36 \cdot 3 & 9 \cdot 0 & 9 \cdot 0\end{array}$

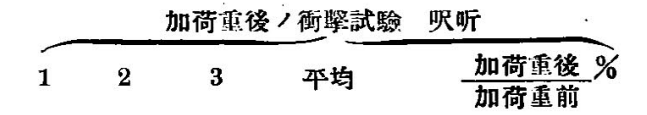

$\begin{array}{rrrrr}26 \cdot 1 & 32 \cdot 0 & 24 \cdot 5 & 27 \cdot 5 & 87 . \\ 11 \cdot 9 & 11 \cdot 0 & 8 \cdot 5 & 10 \cdot 3 & 32 \cdot \\ 16.9 & 13 \cdot 0 & 12 \cdot 7 & 14 \cdot 2 & 45 . \\ 8.8 & 9 \cdot 6 & 7.6 & 87 & 27 .\end{array}$

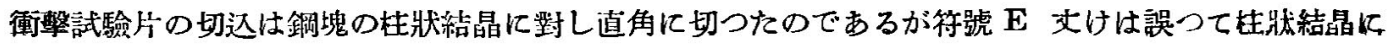
平行に切込んだから衝盤值が高く出た、それでも加荷重前に比べると大に減つて居り全體として荷重 の增す几從つて減り方もひどくなるてとがわかる。

(b) 電氣纑鋼燒鈍つ瑒合: 一電氣爐鋼試驗材番號 5 を第 4 圖（甲）に示す如く切斷し(2)の部分

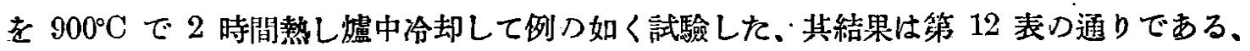

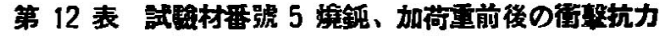

\begin{tabular}{|c|c|c|c|c|}
\hline & 㕍 & 引試 & 殮 & \\
\hline 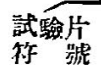 & $\begin{array}{l}\text { 彈性 限 } \\
\mathrm{kg} / \mathrm{mm}^{2}\end{array}$ & $\begin{array}{l}\text { 破断界 } \\
\mathrm{kg} / \mathrm{mm}^{2}\end{array}$ & $\underbrace{\text { 延 }}_{\%}$ & $\begin{array}{c}\text { 收 統 } \\
\%\end{array}$ \\
\hline (2) & $23 \cdot 3$ & 345 & $30-5$ & 53.9 \\
\hline (7) & - & 351 & $24 \cdot 1$ & 50.5 \\
\hline 平 均 & $23 \cdot 3$ & $34 \cdot 8$ & $27 \cdot 3$ & $52 \cdot 2$ \\
\hline
\end{tabular}

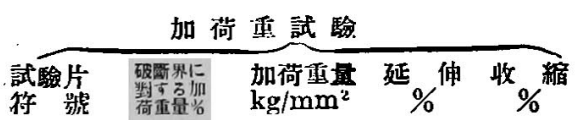

\begin{tabular}{|c|c|c|c|c|c|c|}
\hline & 街 & 綮 & 試 羷 & 吹㗁 & & \\
\hline 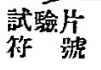 & $\mathbf{1}$ & 2 & 3 & 4 & 5 & 平均 \\
\hline A & 8.8 & $11 \cdot 2$ & 10.5 & 7.8 & $7 \cdot 0$ & $9 \cdot 1$ \\
\hline (B) & 7.2 & 8.0 & 7.0 & $8 \cdot 3$ & 88 & 7.9 \\
\hline
\end{tabular}

$\begin{array}{lllll}\text { (1) } & 60^{\circ} & 21 \cdot 0 & 1.6 & 1 \cdot 6 \\ \text { (3) } & 72 \cdot & 25 \cdot 0 & 3 \cdot 5 & 3 \cdot 5 \\ \text { (5) } & 80^{\circ} & 27 \cdot 9 & 4 \cdot 7 & 4 \cdot 6 \\ \text { (6) } & 90^{\circ} & 31 \cdot 3 & 9 \cdot 0 & 8 \cdot 6\end{array}$

\begin{tabular}{|c|c|c|c|c|c|c|}
\hline & \multicolumn{4}{|c|}{ 加荷重後の衛掔試驗 } & \multicolumn{2}{|c|}{ 呎听 } \\
\hline 1 & 2 & 3 & 4 & $\mathbf{5}$ & & $\frac{\text { 加荷重後 }}{\text { 加琦重前 } \% ~}$ \\
\hline 6.2 & 66 & $6 \cdot 8$ & 6.0 & 6.7 & $6 \cdot 5$ & 76 \\
\hline $5 \cdot 0$ & $5 \cdot 0$ & $4 \cdot 7$ & $5 \cdot 4$ & $5 \cdot 2$ & $5 \cdot 1$ & $59 \cdot$ \\
\hline $4 \cdot 8$ & $7 \cdot 0$ & $5 \cdot 2$ & 6.5 & 6.3 & $6 \cdot 0$ & 70. \\
\hline $5 \cdot 8$ & $5-5$ & $5 \cdot 6$ & 4.9 & $4 \cdot 3$ & 5.2 & $61^{\circ}$ \\
\hline
\end{tabular}




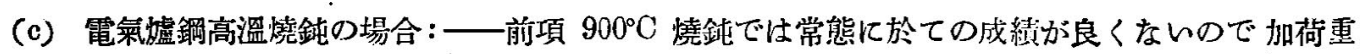

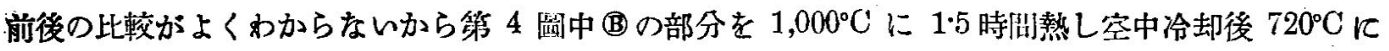
3 時間熱し爐中で $600^{\circ} \mathrm{C}$ 附近汽冷却し其溫度から宾中椧却し第 4 圖（两）の如く試驗片を探つて試 驗したらば第 13 表の如き結果を得た。

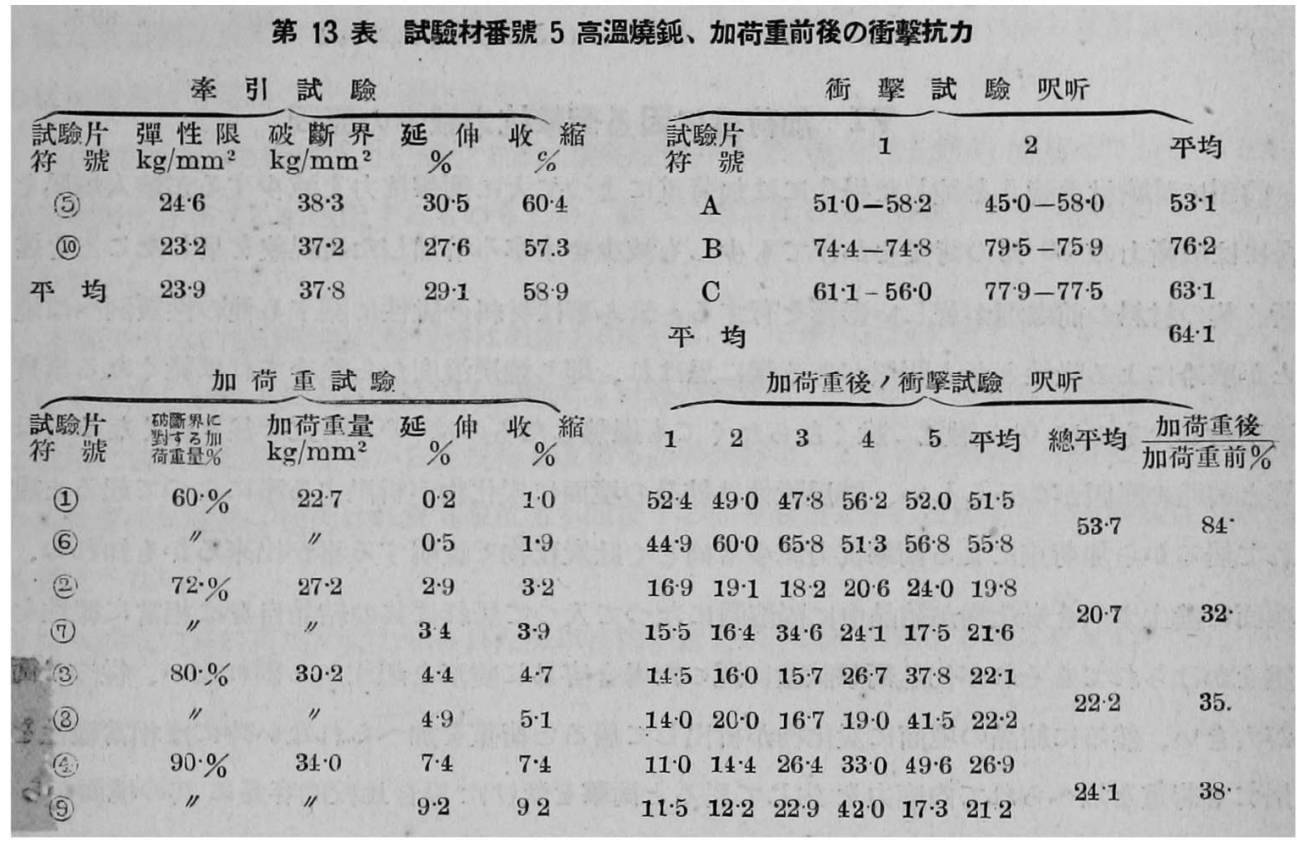

之れによると加荷重 $60 \%$ で少しく衝慗抗力を減じ $72 \%$ 約 $1 / 3$ に減少して居る、それ以上荷重 をかけてもあまりかわらぬ、

（d）電氣爐鋼燒入燒杘の場合: 一一加荷重の影響が其材料の狀態によつて戀化するから燒入燒杘

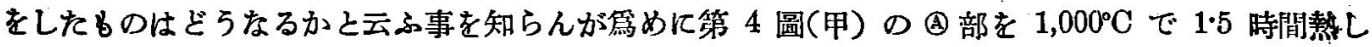
油中冷却後 $650^{\circ} \mathrm{C}$ で 3 時間熱し再び油中椧却したるのから第 4 回(两) と同樣に試驗片を探取して 試驗したら其結果は第 14 表記載の如く今度は $72 \%$ 加街重のものが常溫に於て其睢のものより却つ て $13 \%$ 增加したと云ふ奇現象を呈した尚此際は $0^{\circ} \mathrm{C}$ 於ても試驗して見たらてれは少し減少して居 るがそれでも燒鈍の場合よりも減じ方が大變少ない。

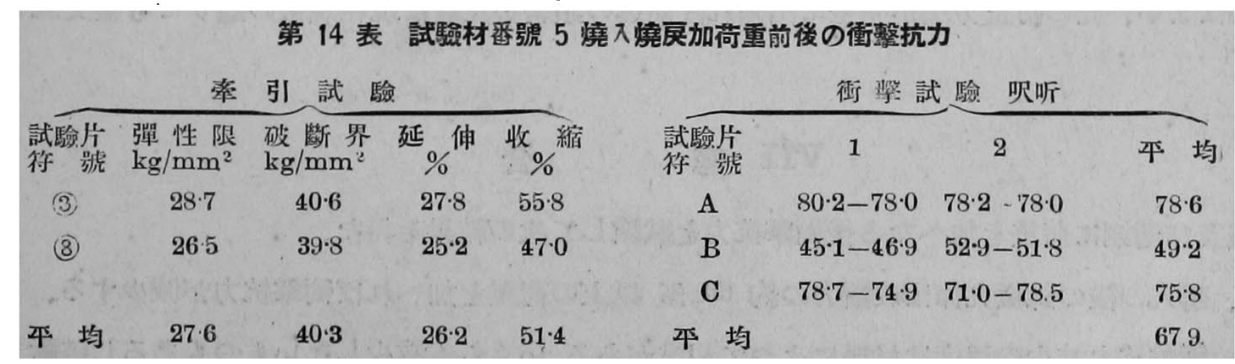




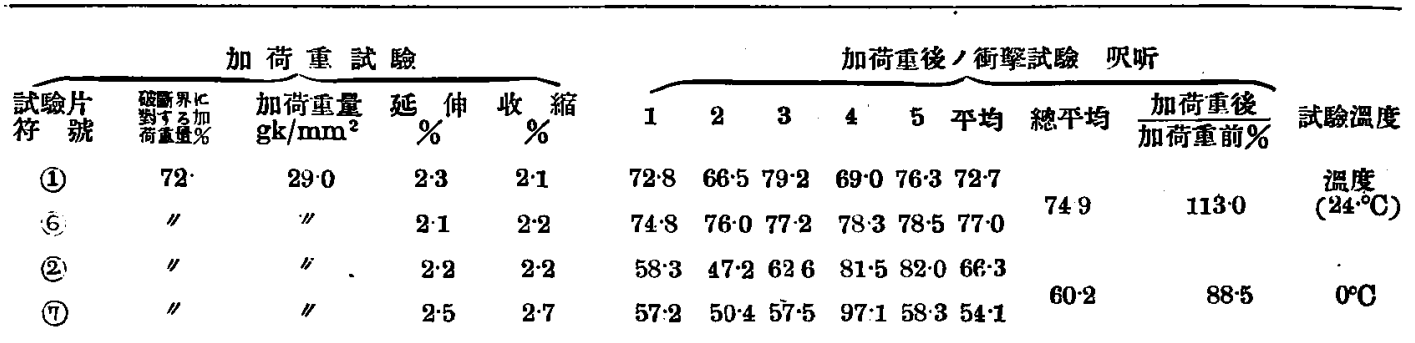

\section{VI 加荷重に因る衝撃抗力減少の原因}

前項に試驗材番號 5 を鈍した場合には加荷重によつて大に衝撃抗力を減少するが燒入燒夺をした場

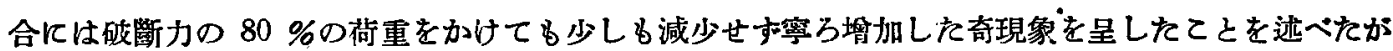
斯く其の材料の前處理が著しい影響を有すると云ふ事は材料の脆性に關する他の性質例人ば燒㞔脆性 とか寒冾による脆性とかと關係がある樣に思はれ、即ち燒㞍溫度から徐冷すれば脆くなる事實や燒入 燒杘をしたものは $0^{\circ} \mathrm{C}$ 附近で脆くならなくても過熱したものは $0^{\circ} \mathrm{C}$ 附近で益ね脆くなると云ふ事筫 等と共通の原因があるらしい、燒戻脆性壮結晶の境面に炭化物が析出する事によつて起ると說明せら れて居るから加荷重による衝撃抗力減少も同じく此炭化物で說明する事が出来るかる知れね、結晶の 境面に發生すべき炭化物が結晶中に固溶體になつて入つて居れば其の結晶自身は相當に颉性を有し荷 重をかけられてもそれが切込衝堑試驗に遇つた場合容易に變形を起すから割れない，從つて舫擊抗力 が大きい、然るに結晶の境面に炭化物が析出して居ると荷重を加へられない時には相當鞄性数つて 居ても荷重を加へられて內應力を生じて居ると衝撃を受けた場合比較的容易に其の境面からら破断す る、即ち衝撃抗力が小さいと云ふ事になる。鍊鐵は非常に炭素が低く本研究に使用した試驗材も炭素

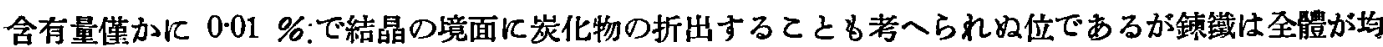
一でないから鈍鐵の部分すあるが多少炭素の多い部分すあり其の部分は結晶境面に炭化物の析出を生 するてとるすり得るから斯かる場合に加荷重に体る衝撃抗力減少を來す樣になるとも考へられる。

以上の說明は之れを確定的のものとするには未だ實驗が不足で種々の處理を行つたものについて加

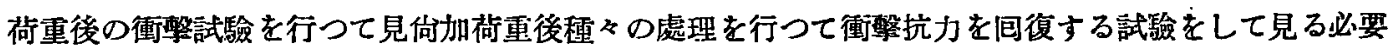
があるが若し加荷重による衝娐抗力減少の原因が上述の通りとすれば之れを防ぐ爲めには脆性を起す べき炭化物の固溶體として殘る如き處理をして置くか或は加荷重後に炭化物を固溶體となす如き處理

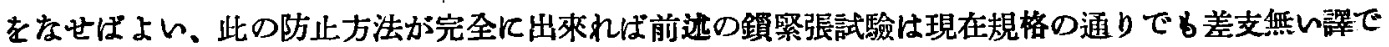
ある。

\section{VII 總合}

鐶臷及ひ篟鋼に荷重を加へたる後衝擊抗力を試驗して次の結果を得た。

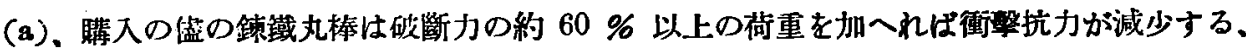

(b)、衝撃抗力減少の程度は材料によつて相迋がある、んくらも減少しないものもあるし破斷力の約 
$72 \%$ 背重で衝擊值が約 $1 / 3$ になるものもある、

（c）鍊鐵試驗材番號 3 K於て $0^{\circ} \mathrm{C}$ の衝撃抗力は荷重をかけないるのに於ては常溫の場合に比し 變化がないが破斷力の $80 \%$ 以上荷重をかけたるのは常溫の約 $1 / 2$ となる、即ち衝盤抗力は加荷重の 雹めに減する上に寒冾の影響で更に牛減する。

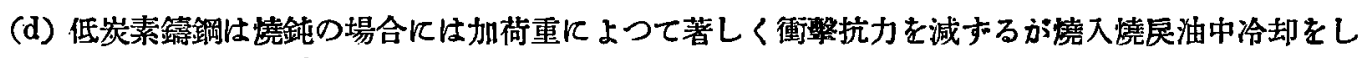
たものは加荷重後も常態の場合と變化がなん、

（e）加荷重によつて重擊抗力を減少するは燒杘脆性の場合の如きは比較的 低溫度で析出する炭化 物が結晶境面に存在するに起因するものらしい，從つて適當なる燒入燒戻を施した材料に於ては此現 象を認めない。

（f）英國や日本の錨鎖緊張試驗規格は破斷力の約 $72 \%$ で索引試驗を施すてとになつて居るが斯

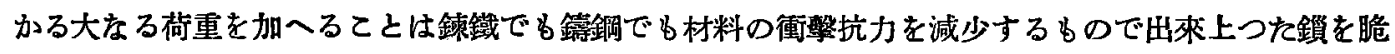
くして實用に供する結果になるから此規格を改める必要がある、尤も像め材料に適當なる燒入燒杘を 施すか或は緊張試驗終了啳失はれた衝撃抗力を回復する如き處理をすれば現規格通りの緊張試驗を施 しても差支へない。

終りに本檏演の資料蒐集に盡力せられた海軍技師宇留野四平氏に深厚なる謝意を表す。(終) 


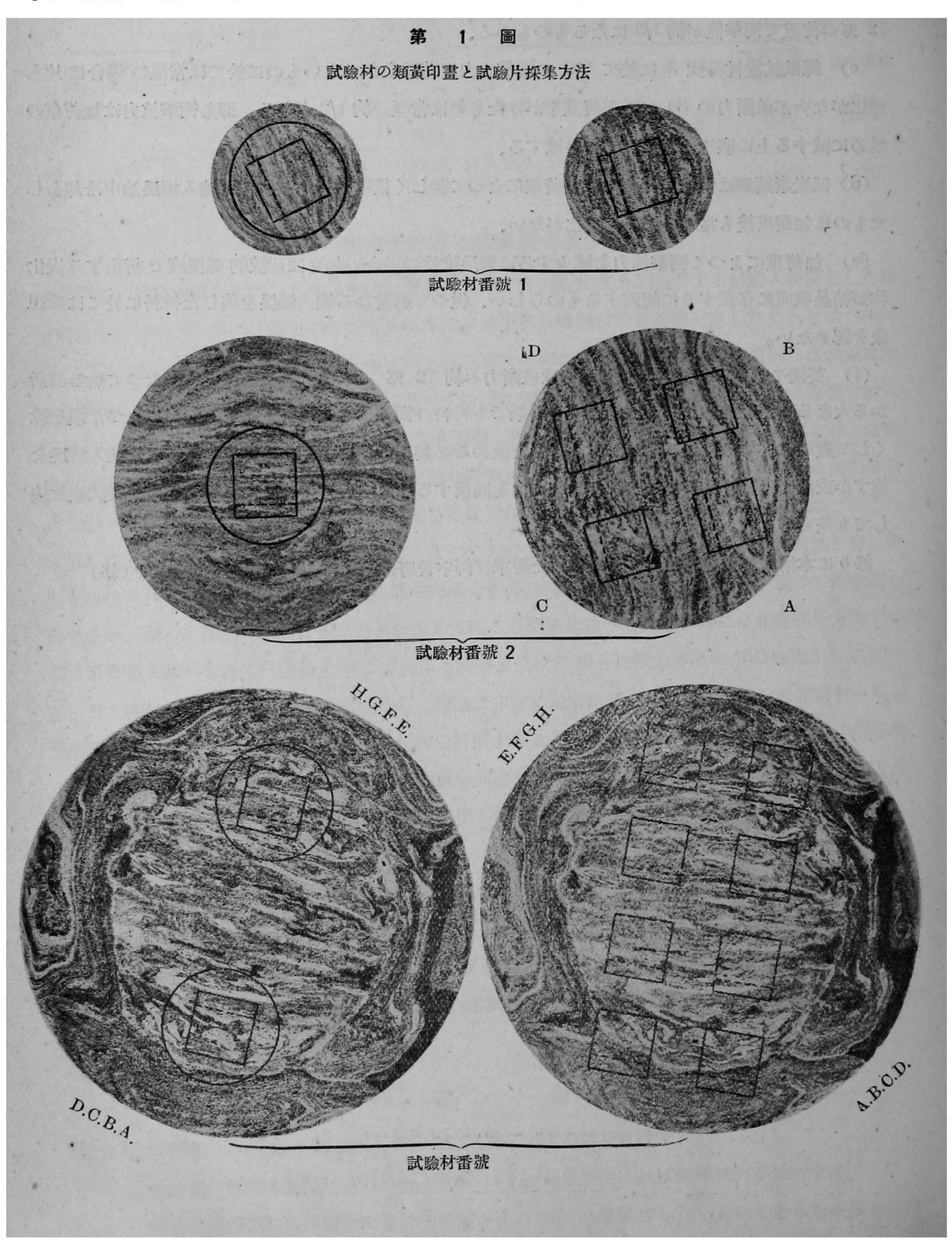


第2 圆

（1）試験锦採取位置

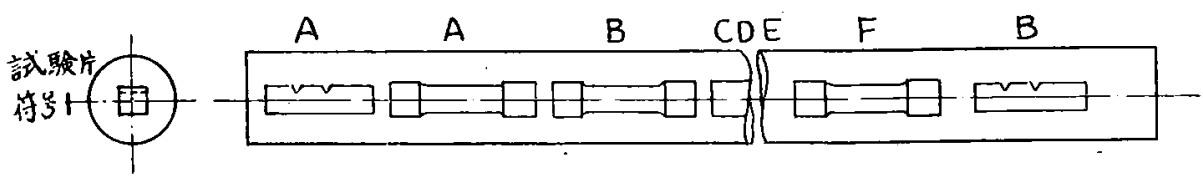
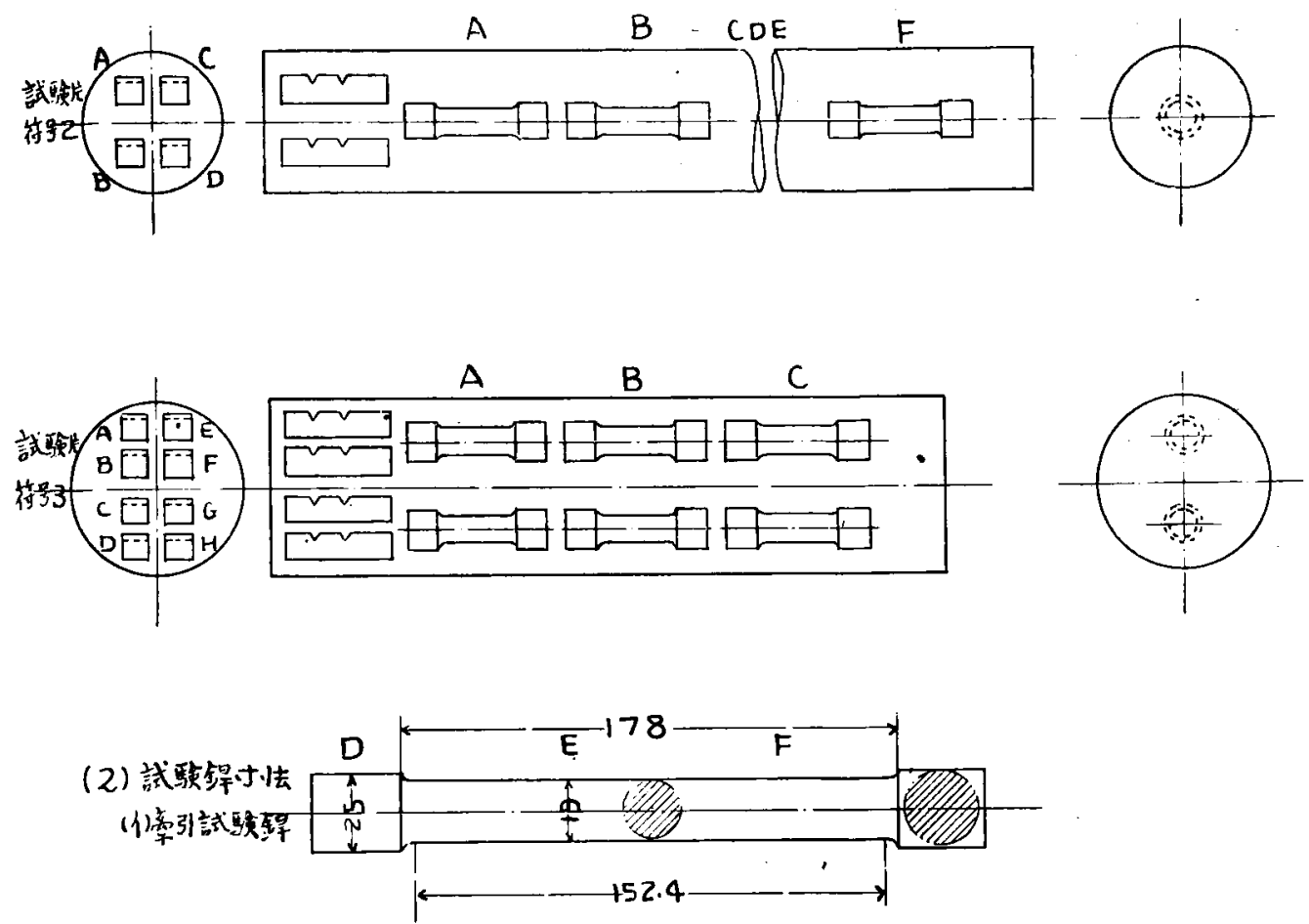

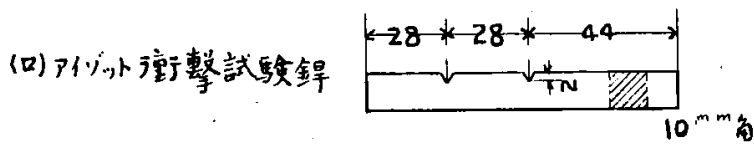

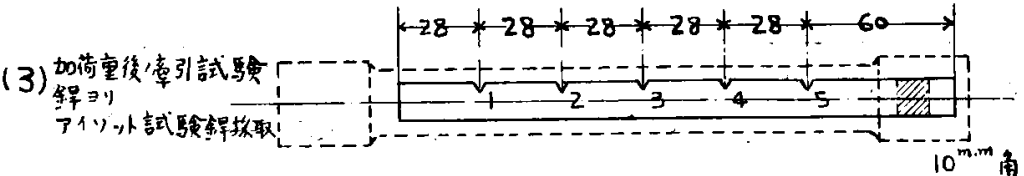




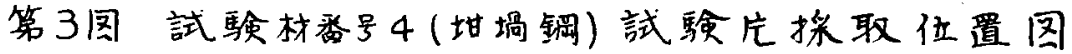
(1) 試駼銲採取位置
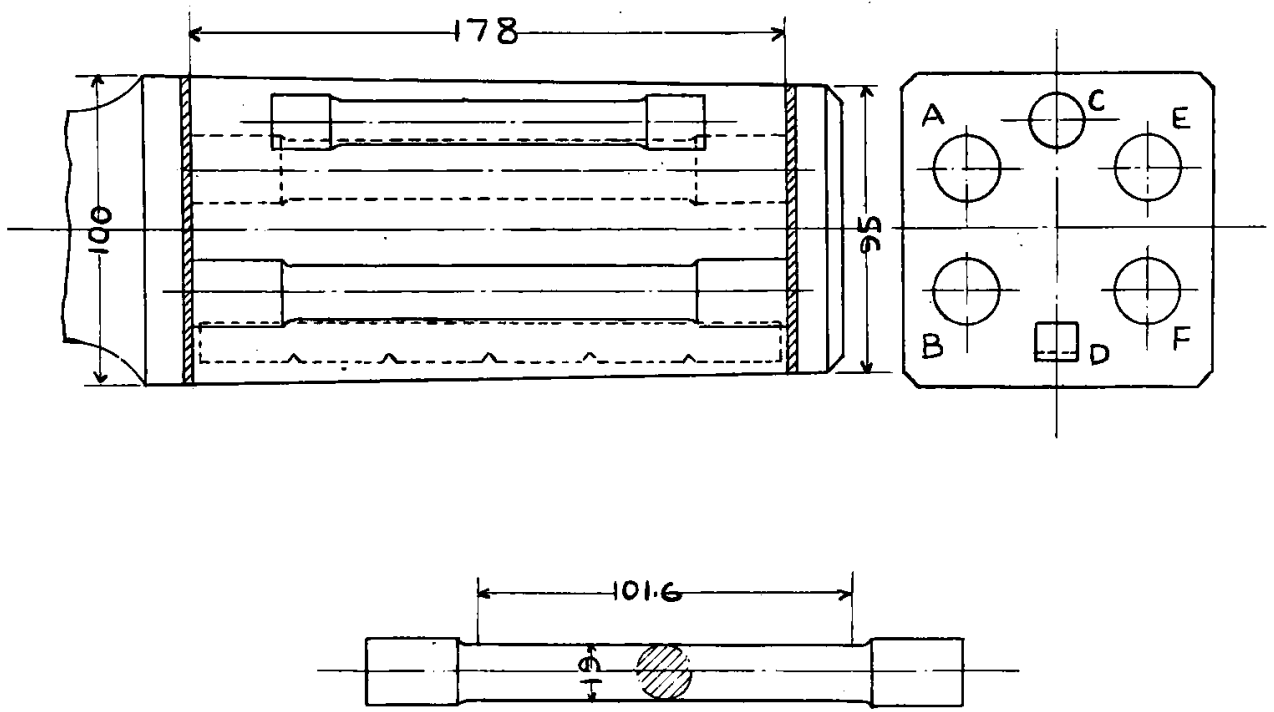

\section{(2) 試䮖銲寸法 (1)亳引試験銲}

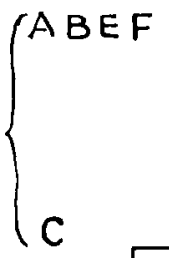

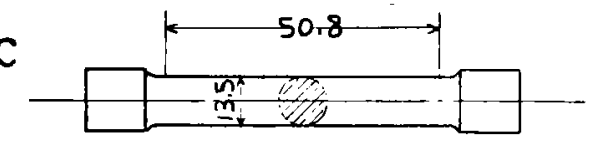

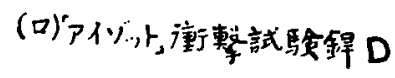

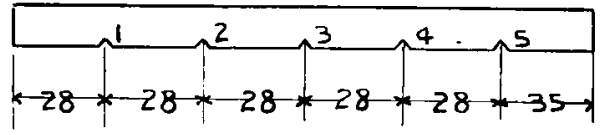

四

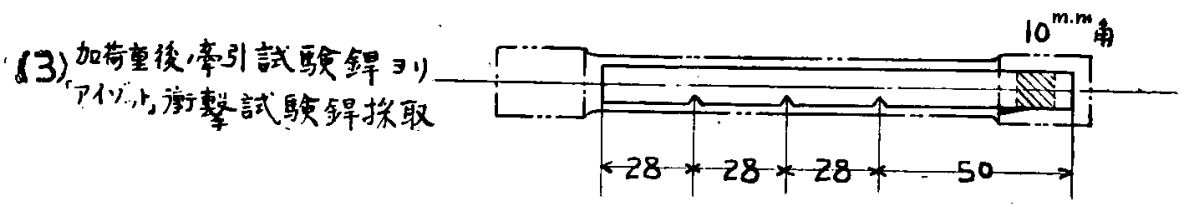




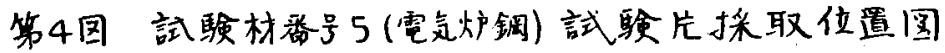

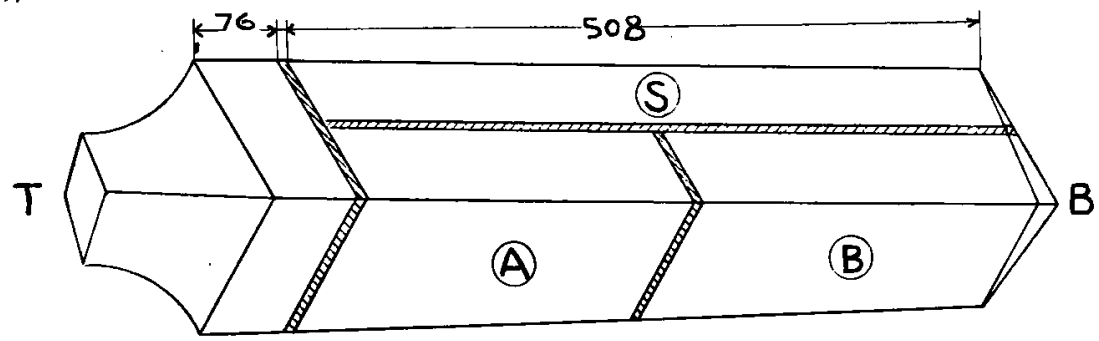

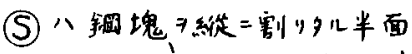

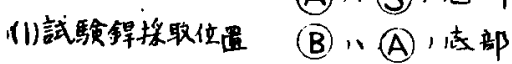
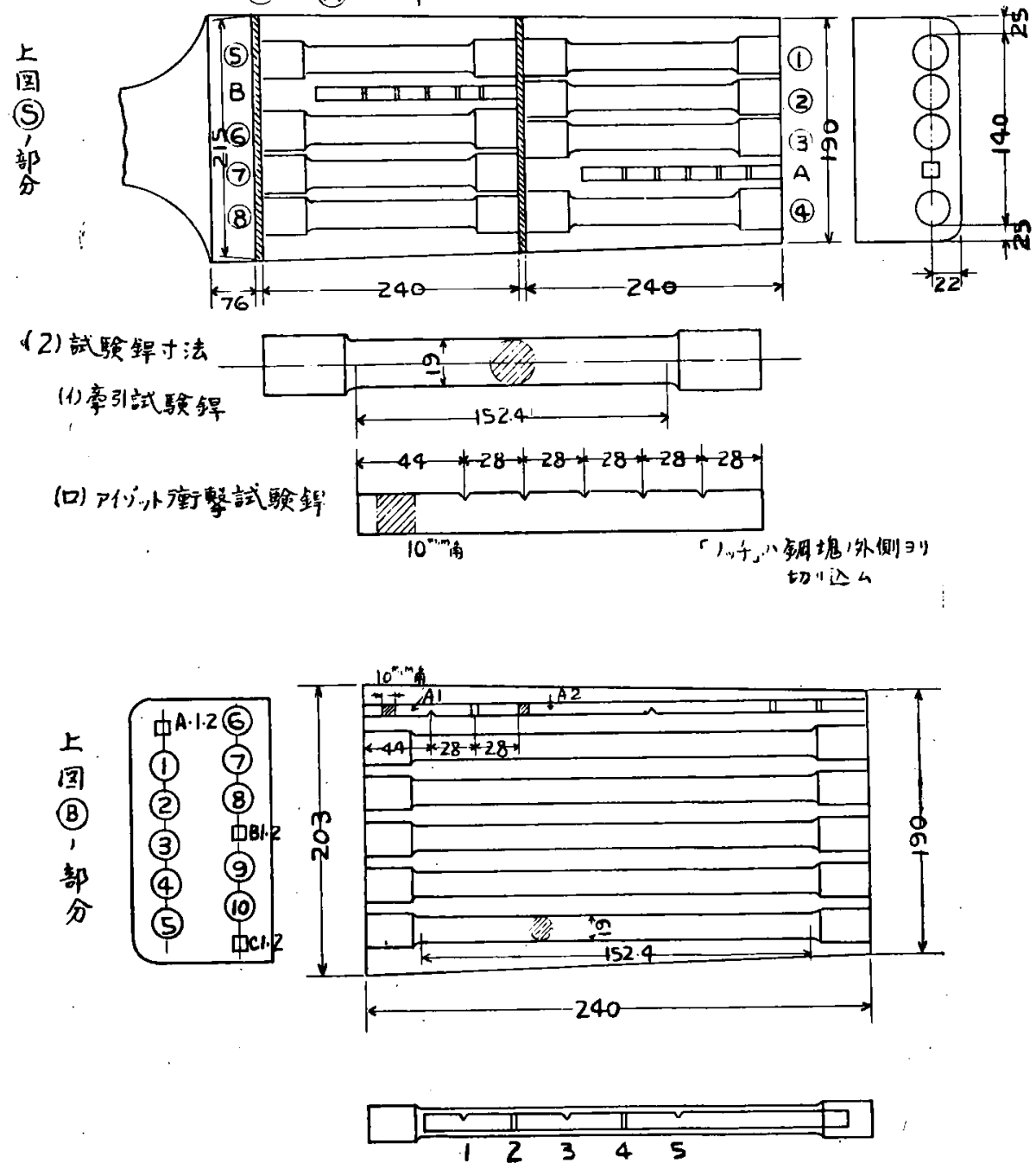

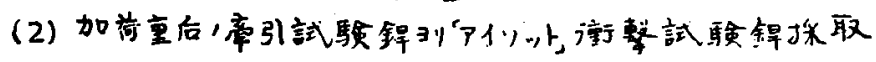

